\title{
Stages of Gas-Hydrate Evolution on the Northern Cascadia Margin
}

\author{
by Michael Riedel, Timothy S. Collett, Mitchell J. Malone, \\ and the IODP Expedition 311 Scientists
}

\section{Introduction}

Natural gas hydrate occurs beneath many continental slopes and in arctic permafrost areas. Recent studies have indicated that the largest deposits of gas hydrate might lie in nearly horizontal layers several hundred meters beneath the seafloor of continental slopes, especially in the large, accretionary sedimentary prisms of subduction zones. Expedition 311 of the Integrated Ocean Drilling Program (IODP) investigated the formation of gas hydrate in the accretionary prism of the Cascadia subduction zone (Fig. 1). The primary objectives of Expedition 311 were to test and constrain geological models of gas hydrate formation by upward fluid and methane transport in accretionary prisms. We specifically sought to (a) determine the mechanisms that control the nature, magnitude, and distribution of the gas hydrate, (b) find the pathways of the fluid migration required to form large concentrations of gas hydrate, (c) examine the effects of gas hydrate on the physical properties of the host sediment,

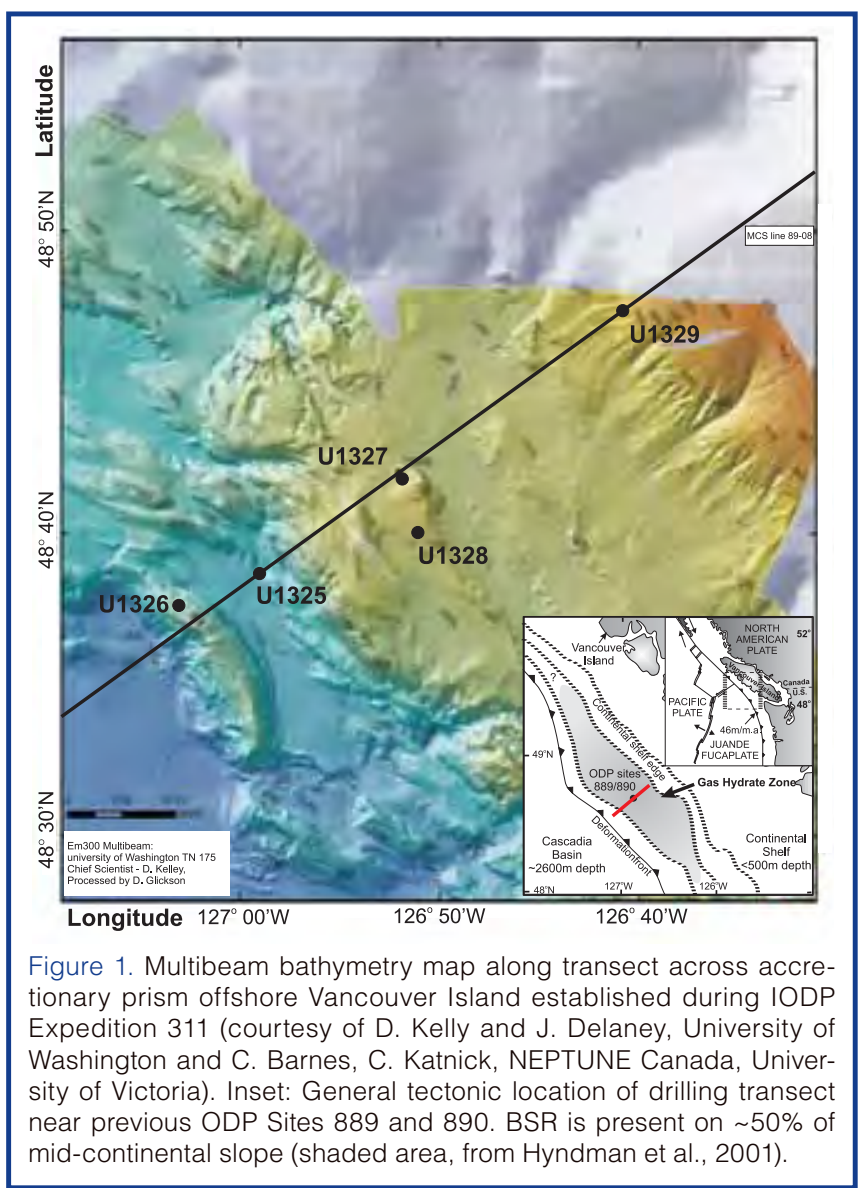

and (d) investigate the microbiology and geochemistry associated with the occurrence of gas hydrate. Furthermore, we concentrated on the contrast between methane transport by focused flow in fault zones and by dispersed pervasive upward flow at various scales of permeability.

\section{Background}

Along the northern Cascadia margin, the Juan de Fuca plate converges nearly orthogonally to the North American plate at a present rate of $\sim 45 \mathrm{~mm} \cdot \mathrm{y}^{-1}$ (e.g., Riddihough, 1984). Seaward of the deformation front, the Cascadia Basin consists of pre-Pleistocene hemipelagic sediments overlain by rapidly deposited Pleistocene turbidites for a total sediment thickness of $\sim 2500 \mathrm{~m}$. Most of the incoming sediment is scraped off the oceanic crust and folded and thrust upward to form elongated anticlinal ridges that reach as high as $700 \mathrm{~m}$ above the adjacent basins.

A general model for forming gas hydrate by removal of methane from upwardly expelled fluids was proposed for the study area (Hyndman and Davis, 1992). Mainly microbial methane, inferred to be produced over a thick sediment section, migrates vertically and forms gas hydrate when it enters the stability field. The highest concentration of gashydrate is predicted to occur just above the bottom-simulating reflector (BSR). A model has also been proposed for how free gas and the resulting BSR will form as the base of gas hydrate stability moves upward as a result of post-Pleistocene seafloor warming, uplift, and sediment deposition (e.g., Paull and Ussler, 1997; von Huene and Pecher, 1998). In addition, physical and mathematical models have been developed for the formation of gas hydrate from upward methane advection and diffusion (e.g., Xu and Ruppel, 1999).

Recently, evidence has been identified for focused fluid or gas flow and gas-hydrate formation on the Vancouver margin. The most studied site is an active cold-vent field associated with near-surface gas-hydrate occurrences (e.g., Riedel et al., 2002) and with fault-related conduits for focused fluid or gas migration. It is unknown how important these cold vents are in the total budget of fluid flow in an accretionary prism.

\section{Results}

On Expedition 311, we drilled a transect of four sites (U1325, U1326, U1327, and U1329) across the northern 


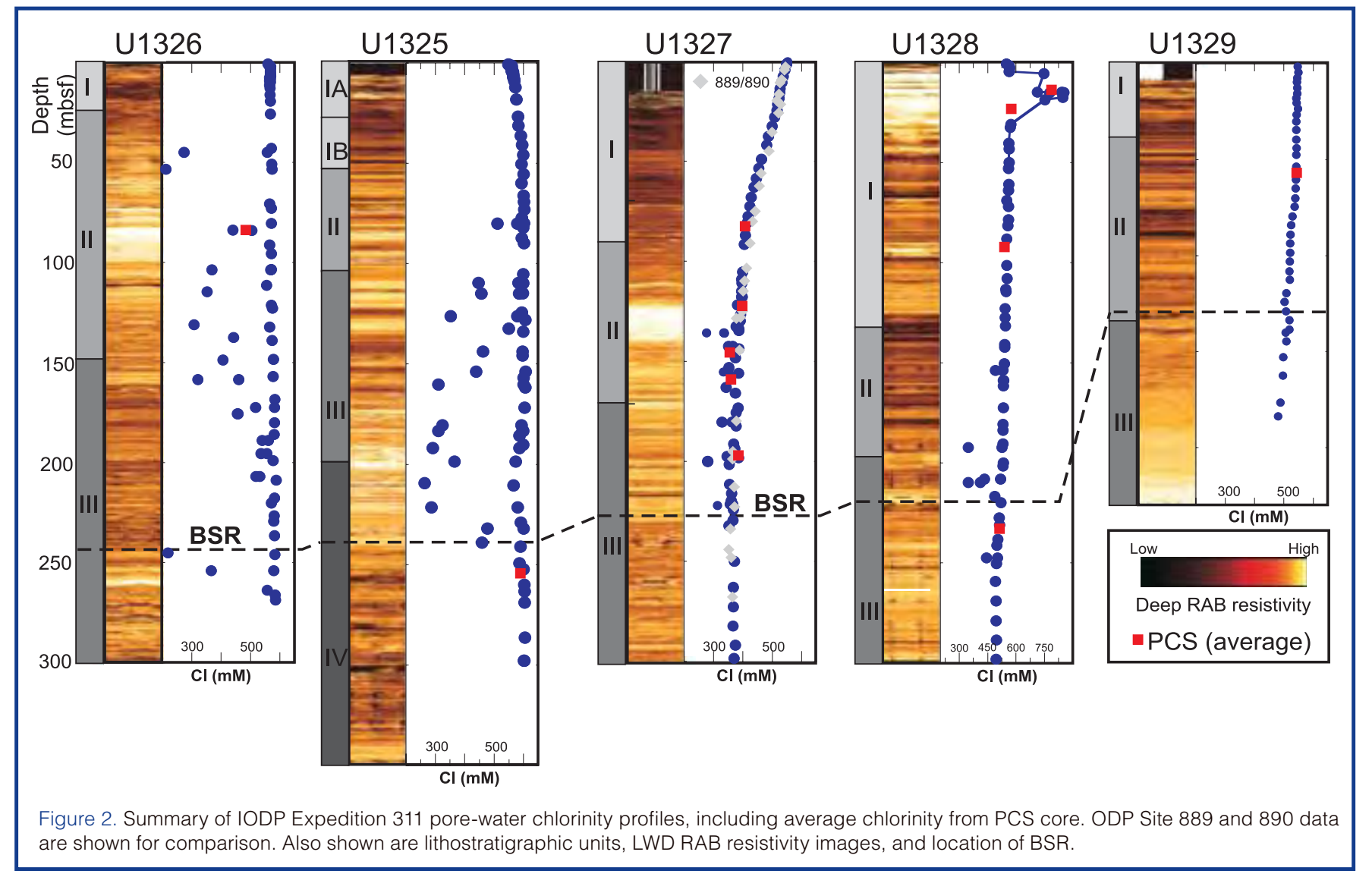

Cascadia margin and a fifth site (U1328) at a nearby cold vent with active fluid and gas flow. The four transect sites represent different stages in the evolution of gas hydrate across the margin from the earliest occurrence on the westernmost, first-accreted ridge (Site U1326) to its final stage at the eastward limit of gas-hydrate occurrence on the margin in shallower water (Site U1329). Logging-whiledrilling and measurement-while-drilling (LWD/MWD) conducted prior to coring provided a set of measurements that guided subsequent coring and special tool deployments at all five sites. We also completed additional wireline logging at each site and two vertical seismic profiles (VSP) at Sites U1327 and U1328. A total of $1217.76 \mathrm{~m}$ of sediment core was recovered using the advanced piston corer (APC) and extended core barrel (XCB) systems. Standard coring was interspersed with pressure-core-sampler (PCS) runs for onboard degassing experiments and special Hydrate Autoclave Coring Equipment (HYACE) tools In New Tests on Hydrates (HYACINTH) pressure-coring deployments, four of which were stored under in situ pressure for subsequent shore-based studies.

Infrared imaging was used to identify quickly any gas hydrate that may have been present in the recovered core and that may have been available for direct sub-sampling and preservation with liquid nitrogen. Special care also was taken to sample cold infrared anomalies for pore-water chlorinity to confirm the presence of gas hydrate as well as sampling for shore-based microbiological analyses.
At each site, we tried to accomplish a three-hole conventional coring, specialized coring, and logging approach to maximize the scientific objectives. The first hole (Hole A) was always dedicated to LWD/MWD operations. All LWD/ MWD holes were drilled during the first week of the expedition and were followed by coring and conventional wireline operations. In most cases, the second hole (Hole B) was for continuous coring, temperature measurements, and PCS coring to establish complete downhole profiles of gashydrate proxies such as pore-water chlorinity, infrared images, etc. The third hole (Hole C) was dedicated to special tool deployments, especially the two HYACINTH pressurecoring systems, the Fugro Pressure Corer (FPC) and HYACE Rotary Corer (HRC), and additional PCS deployments. In all coring holes, we tried to recover a detailed temperature profile by regularly deploying the Advanced Piston Corer Temperature tool (APCT), the third generation Advanced Piston Corer temperature tool (APC3) and the Davis-Villinger Temperature Pressure Probe (DVTPP); however, severe weather conditions during portions of the expedition resulted in degraded data quality for some deployments and in less-than-optimal constraints on the temperature gradient at all sites.

All results from the drilling transect and the cold-vent site are presented in Figures 2-4 as a collage of lithostratigraphic units and resistivity-at-the-bit (RAB) images from the LWD/ MWD deployment compared with pore-fluid chlorinity (Fig. 2), sediment gas geochemistry (Fig. 3), and gas-hydrate concentration estimates using the RAB data (Fig. 4). The 
approximate depths of the BSR as predicted from seismic site-survey data are also shown.

\section{Site U1326}

Site U1326 is the westernmost site of the transect and is located on the first uplifted ridge of the accretionary wedge. Many faults intersect the sediment column from the seafloor to below the BSR. Newly acquired multibeam bathymetry data showed a prominent collapse feature near the original primary location, which forced a switch to the alternate site. The faults identified on the seismic data showed linear features on the bathymetry map crossing the ridge around the collapse feature and have seafloor displacements of up to $20 \mathrm{~m}$.

The 271.4-m-thick Quaternary sedimentary section cored at Site U1326 is divided into three lithostratigraphic units. Soupy and mousse-like textures indicative of gas-hydrate occurrence are observed in Units II and III to a maximum depth of 246 mbsf.

At Site U1326, only one PCS core (Core 311-U1326C-12P; $83.7 \mathrm{mbsf}$ ) was recovered under pressure and investigated by controlled shipboard degassing experiments. LWD/ MWD-derived RAB images from Hole U1326A indicate the presence of high-resistivity gas-hydrate intervals between 72 and 240 mbsf (Figs. 2-4). Gas-hydrate-rich layers alternate with low-resistivity layers that likely contain little or no gas hydrate. Calculation of water saturations from electricalresistivity logging data yield evidence for relatively shallow gas-hydrate occurrences at this site between $\sim 50$ and $100 \mathrm{mbsf}$, with inferred gas-hydrate concentrations as high as $80 \%$ of the pore space. P-wave velocities measured by wireline logging in Hole U1326D show highly variable values (between 1750 and $>3000 \mathrm{~m} \cdot \mathrm{s}^{-1}$ ) in the same high-resistivity interval. The high $\mathrm{P}$-wave velocity values are consistent with high gas-hydrate concentrations.

The chlorinity data from Site U1326 show an almost constant baseline trend of near seawater values with depth (Fig. 2). Chlorinity anomalies associated with gas hydrate actually may extend to $270 \mathrm{mbsf}$ at this site, which is deeper than the estimated BSR depth of $230 \mathrm{mbsf}$. This apparent disparity between the predicted depth of the BSR and the observed occurrence of gas hydrate may be explained by the borehole temperature measurements that yield a methanehydrate stability zone depth of $275 \pm 25 \mathrm{mbsf}$; however, most data from the temperature tool deployments are degraded, and we have extrapolated the temperature data from Site U1325 for this calculation.

Hydrocarbon headspace-gas measurements from Holes U1326C and U1326D show that methane is the dominant hydrocarbon gas within the cored interval (Fig. 3). The $\mathrm{C}_{2+}$ hydrocarbon void-gas concentrations are $<125 \mathrm{ppmv}$ (parts per million by volume) for all samples. Low $\mathrm{C}_{1} / \mathrm{C}_{2}$ ratios within the interval from $\sim 35$ to $\sim 72 \mathrm{mbsf}$ are associated with two recovered gas-hydrate samples. With greater depth, ethane concentrations return to the near-surface concentrations close to the predicted depth of the BSR. Isobutane concentrations are also elevated within the same interval, which may indicate the presence of Structure II gas hydrate. The occurrence of more complex hydrocarbon gases in combination with the pore-water chlorinity baseline shift with depth generally indicates the contribution of a deeper gas source.

\section{Site U1325}

Site U1325 is located near the southwestern end of the drilling transect and lies within a major slope basin that developed eastward of the deformation front behind a steep ridge of accreted sediments (Fig. 1). The site is underlain by a relatively weak BSR, which appears to be at $230 \pm 5$ mbsf using simple seismic travel-time depth conversion with an average P-wave velocity of $1636 \mathrm{~m} \cdot \mathrm{s}^{-1}$ as defined from the ODP Site 889 VSP survey (MacKay et al., 1994).

Four holes were occupied at Site U1325. Hole U1325A was dedicated to the pre-coring LWD/MWD deployment, and Holes U1325B, U1325C, and U1325D recovered a 304.3-m-thick sediment section that was divided into four lithostratigraphic units based on visual inspection of the recovered cores. Examination of diatoms from Holes U1325B and U1325C indicated that the sediments cored at Site U1325 are mostly Quaternary in age.

Pressure coring proved difficult at this site. Out of the seven attempts using the PCS, FPC and HRC, only the deepest PCS (256.5 mbsf) recovered sediment under pressure.

LWD/MWD-derived RAB images from Hole U1325A suggested that gas hydrate is concentrated in thin sand layers between 173 and 240 mbsf (Figs. 2-4). The LWD/ MWD porosity and resistivity logs showed further that it is a very heterogeneous gas-hydrate-bearing section composed of alternating layers of gas-hydrate-saturated sands and clayrich layers with little to no gas hydrate. This interpretation generally agrees with the marked freshening of the interstitial water observed in sampled sand layers.

The salinity and chlorinity profiles indicate an advective transport system with the occurrence of higher-thanseawater salinity and chlorinity values of $\sim 36$ and $\sim 600 \mathrm{mM}$, respectively (Fig. 2). The elevated solute concentration might be caused by low-temperature diagenetic hydration reactions, probably the alteration of volcanic ash to clay minerals or zeolites in the deeper parts of the basin. In the zone extending from 70 to $240 \mathrm{mbsf}$, salinity and chlorinity data show discrete excursions to fresher values, indicating that gas hydrate was present in the cores and had dissociated prior to processing the samples. 


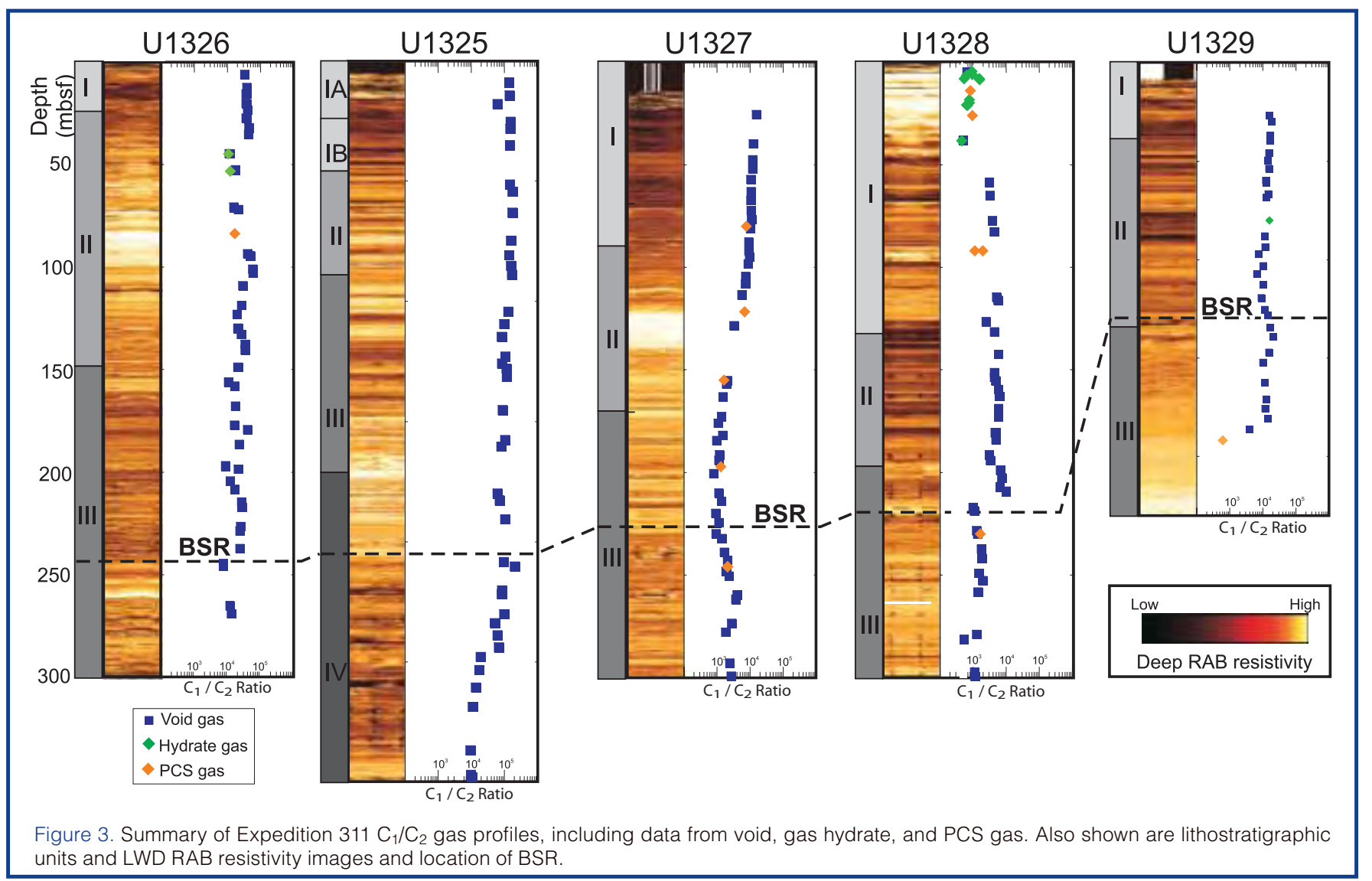

Organic geochemical studies of headspace samples, void gas, and gas samples recovered during the PCS degassing experiment indicate that the recovered gas was almost entirely methane with a small percentage of carbon dioxide ( 0.1-0.5\%). Trace quantities of $\mathrm{C}_{2+}$ hydrocarbons ( $\left.<5 \mathrm{ppmv}\right)$ are present above the predicted BSR depth (Fig. 3). With greater depth, the concentrations of ethane, propane, and isobutane increase but do not exceed 15 ppmv. Decreasing $\mathrm{C}_{1} / \mathrm{C}_{2}$ values below the $\mathrm{BSR}$ indicate a slight thermogenic or diagenetic contribution of ethane.

\section{Site U1327}

Site U1327 is located near ODP Sites 889 and 890 (Westbrook et al., 1994), approximately at the mid-slope of the accretionary prism over a clearly defined BSR estimated at 223 mbsf. Site U1327 is located near two prominent topographic highs rising $>200 \mathrm{~m}$ above the surrounding seafloor and is characterized by a $\sim 90$-m-thick cover of slopebasin sediments underlain by a thick section of accreted sediments (Fig. 1). The 300-m-thick sediment section recovered at Site U1327 is divided into three lithostratigraphic units, with the boundary between Units I and II coinciding with the seismostratigraphic boundary between slope and accreted sediments. Soupy and mousse-like sediment textures related to the presence of observed gas hydrate are detected only in Unit II to a maximum depth of 161.85 mbsf.
From $128 \mathrm{mbsf}$ to the depth of the BSR, the chlorinity and salinity profiles exhibit distinct anomalies that indicate freshening as a result of the dissociation of gas hydrate during the core recovery process (Fig. 2). Chloride values as low as $70 \mathrm{mM}$ (salinity $=3.7$ ) correlate to individual turbidite sand layers. Such a low pore-water chlorinity is equivalent to a pore-space gas-hydrate concentration of $\sim 80 \%$. No chlorinity anomalies occur below $\sim 225$ mbsf, which is close to the predicted depth of the BSR. The strongly decreasing chlorinity profile from the surface to below the BSR suggests mixing between in situ seawater and deeply sourced, modified, relatively fresh pore water. Pore-water chlorinity and salinity remain almost constant beneath the BSR.

Methane is the predominant hydrocarbon gas found in the cores from Site U1327. Ethane concentrations are generally low but increase in the void and headspace gases collected from the stratigraphic section overlying the projected depth of the BSR. This increase in ethane concentrations is reflected in the $\mathrm{C}_{1} / \mathrm{C}_{2}$ void gas ratios, which decrease with depth toward the BSR (Fig. 3).

Pre-coring LWD/MWD in Hole U1327A showed a thick section of consistently high electrical resistivities and low density values at a depth of $120-138$ mbsf. This section was the target of several pressure cores in the adjacent holes, but we failed to recover core under pressure. Calculated values of pore-water saturation suggest gas-hydrate concentrations as high as $50 \%$ of the pore volume in this interval; however, the same interval was penetrated in the adjacent Holes 


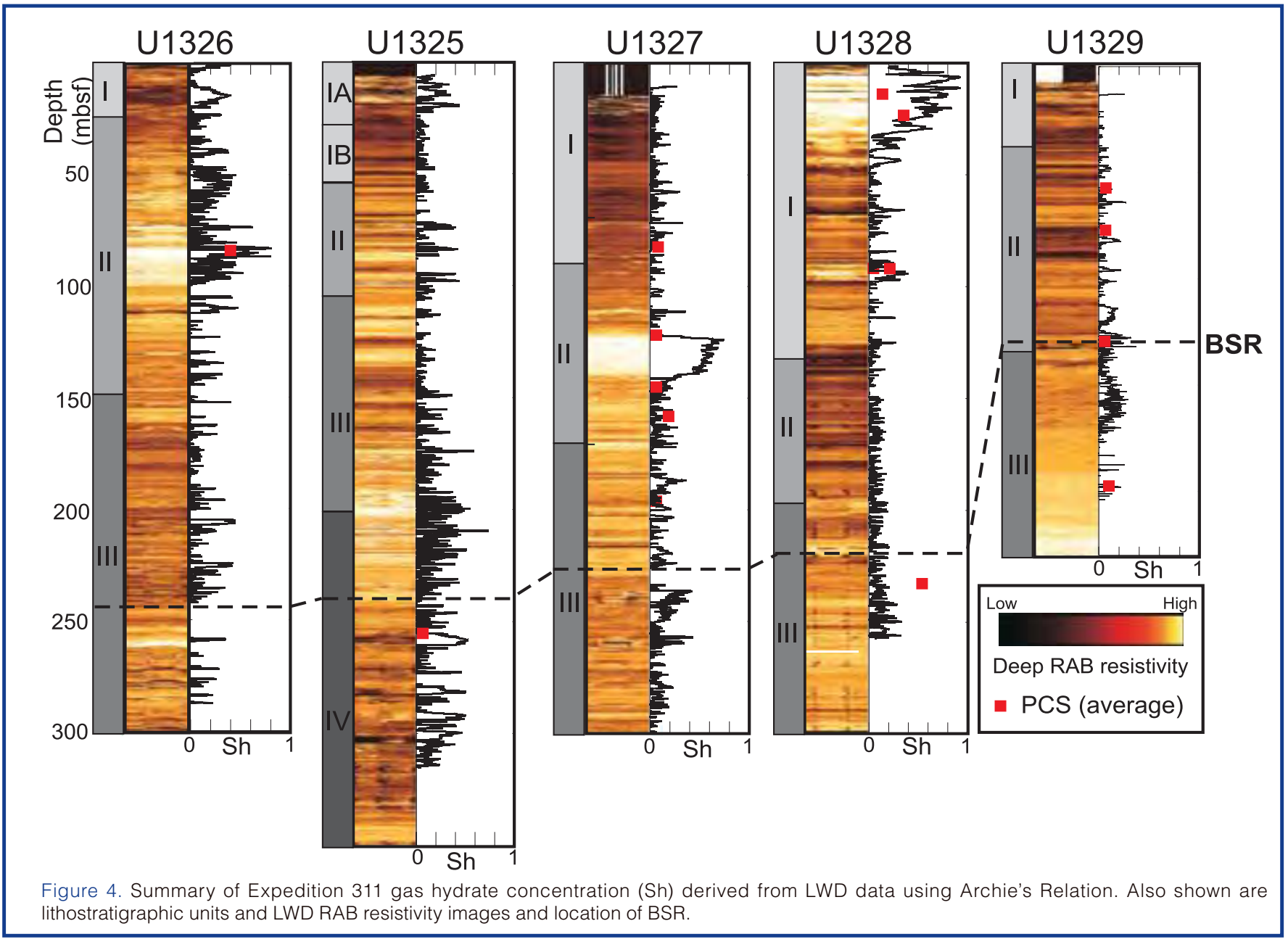

U1327C and U1327D at much greater depths and with lower estimated gas hydrate concentrations inferred from the wireline electrical log in Hole U1327D. No evidence of this interval was found in the wireline logs in Hole U1327E. This demonstrates large intrasite variability in gas hydrate content that is probably controlled by lithostratigraphic changes or structural complexities. This observation has dramatic implications on the calibration of geophysical surveying techniques such as seismic methods or controlled-source electromagnetic surveys that are commonly used to detect and quantify gas hydrate.

\section{Site U1329}

Site U1329 lies at the eastern end of the drilling transect and is believed to be at the eastern limit of gas hydrate occurrence on the northern Cascadia margin. A faint BSR was identified in the site-survey data at 126 mbsf. Site U1329 is located near the foot of a relatively steep slope, and sedimentation at this site is dominated by slope processes. The stratigraphy at Site U1329 is divided into three lithostratigraphic units with the boundary between Units II and III marked by the occurrence of an unconformity. Biostratigraphic analyses show that sediments of Unit III are of late Miocene age ( $>6.7 \mathrm{Ma}$ ), whereas sediments in Unit II range from 0.3 to $2.0 \mathrm{Ma}$. The unconformity thus represents $\sim 4$ m.y. of missing sediment which was likely eroded.
The recovered sedimentary section did not show any signs of prominent infrared anomalies or soupy or mousse-like textures indicative of the presence of gas hydrate. Similarly there are no obvious anomalies in the pore-water chlorinity profile (Fig. 2).

The predominant hydrocarbon gas found in the cores from Site $\mathrm{U} 1329$ is methane. The $\mathrm{C}_{1} / \mathrm{C}_{2}$ ratios are generally high, suggesting a microbial origin for the observed methane (Fig. 3). Samples collected from deeper than $180 \mathrm{mbsf}$ at this site, however, exhibited significant increases in $\mathrm{C}_{2}-\mathrm{C}_{5}$ concentrations, which suggests an influence from a thermogenic hydrocarbon source.

\section{Site U1328}

Site U1328 is located within a seafloor cold-vent field consisting of at least four vents associated with near-surface faults. The cold vents are characterized by seismic blank zones that are between eighty and several hundred meters wide and show a clear east-west trend as identified from 3-D seismic imaging (Riedel et al., 2002). We targeted the most prominent vent in the field, referred to as Bullseye vent, which has been the subject of intensive geophysical and geochemical studies since 1999 (e.g., Riedel et al., 2006; Wood et al., 2002). Site U1328 differs from the four other sites visited during this expedition in that it represents an 
area of active, focused fluid flow. Several mechanisms have been proposed to explain the seismic blanking and nature of fluid venting in the Bullseye vent area (Riedel et al., 2002, 2006; Zuehlsdorff and Spiess, 2004; Wood et al., 2002). The objectives of coring and logging at this location were to test the different models for the cold-vent structure and associated causes of seismic blanking, the rate of methane advection, and the potential loss of methane into the water column.

Five holes were drilled at Site U1328. Hole U1328A was dedicated to LWD/MWD measurements to a total depth of 300 mbsf. At Site U1328, a 300-m-thick sequence of Quaternary (0 to $<1.6 \mathrm{Ma}$ ) slope and slope basin sediment was recovered in Holes U1328B, U1328C, and U1328D and was divided into three lithostratigraphic units. Hole U1328E was used to conduct a VSP experiment with the deepest clamping position at $286 \mathrm{mbsf}$.

At Site U1328, massive gas hydrate was sampled near the seafloor, and evidence of gas hydrate was found in the recovered cores in the form of soupy and mousse-like textures and cold infrared anomalies.

The most striking feature in the LWD/MWD logs from site U1328 is the occurrence of layers with high resistivities ( $>25 \Omega \mathrm{m})$ alternating with zones of lower resistivity $(1-2 \Omega \mathrm{m})$ in the upper $46 \mathrm{mbsf}$. The high resistivities likely indicate the presence of gas hydrate. Below this uppermost highresistivity zone, the LWD/MWD logs do not show much evidence for the presence of gas hydrate, except for a few intervals where steeply dipping fractures with high resistivity values, probably the result of gas hydrate, were penetrated. These fractures might act as gas migration conduits that feed the gas-hydrate accumulation observed near the seafloor.

The combined analysis of wireline logging, acoustic velocities, and waveform amplitudes identify the occurrence of free gas in the interval between 210 and 220 mbsf, near the predicted depth of the BSR at $\sim 219$ mbsf in Hole U1328C, where the $\mathrm{P}$-wave velocity drops slightly and the S-wave velocity increases. Additional evidence for the occurrence of free gas below the BSR is noted in the analysis of the LWD/ MWD acoustic coherence data, borehole fluid-pressure response during drilling, and the wireline P-wave, resistivity, density, and neutron logs. The PCS degassing experiments of a single core in Hole U1328E also indicate the presence of a free gas phase below the BSR at this site; however, the VSP experiment conducted in Hole U1328E yielded uniform velocities near $1645 \mathrm{~m} \cdot \mathrm{s}^{-1}$ for the entire depth range between 105 and 286 mbsf and thus did not show any sign of gas hydrate or free gas.

The composite chlorinity profile for this site shows four distinct zones (Fig. 2). In the upper $\sim 40 \mathrm{~m}$ of the hole, a striking increase in chlorinity is seen with maximum values exceeding $850 \mathrm{mM}$. This is interpreted as a result of salt exclusion during in situ gas-hydrate formation that has not been removed by advective or diffusive processes. The second zone from $\sim 40$ to $\sim 150 \mathrm{mbsf}$ is characterized by linearly decreasing chlorinity values ranging from 538 to $570 \mathrm{mM}$. A third zone, extending 150-250 mbsf across the BSR, showes discrete excursions to fresher chlorinity values as low as $348 \mathrm{mM}$, suggesting that gas hydrate was present in the cores and had dissociated prior to processing the samples. In the deepest zone, below $250 \mathrm{mbsf}$, the chlorinity remains nearly constant at $493 \pm 3 \mathrm{mM}$, suggesting communication with a fluid at greater depth that is notably different in composition from the deep-seated fluid sampled at Sites U1327 and ODP Sites 889 and 890.

Geochemical analyses of headspace and void-gas samples show that methane is the most prominent hydrocarbon gas at Site U1328 (Fig. 3). Ethane was also present in almost all of the headspace samples, and the concentrations of ethane, propane, and isobutane increase at and below the predicted depth of the BSR. The occurrence of propane and elevated isobutane to n-butane $\left(\mathrm{i}-\mathrm{C}_{4} / \mathrm{n}-\mathrm{C}_{4}\right)$ ratio suggests that the gas hydrate near the BSR contains Structure II gas hydrate.

\section{Summary}

IODP Expedition 311 established the first margin-wide transect of drilling sites through an accretionary prism expressly to study gas hydrate. The sites represent various stages in the gas-hydrate formation history capturing typical accretionary wedge environments such as accreted ridges and slope basins filled with either undisturbed or slightly deformed slope sediments and accreted sediments that lack seismic coherency as a result of tectonic stresses.

Indirect evidence of the presence of gas hydrate includes increased electrical resistivities and $\mathrm{P}$-wave velocities on downhole $\log$ s, low chlorinity and low salinity pore-water anomalies, numerous infrared cold spots, and decreases in void gas $\mathrm{C}_{1} / \mathrm{C}_{2}$ ratios, as well as moussey and soupy sedimentary textures in recovered cores. Gas hydrate was also observed directly in recovered cores, and more than thirty gas hydrate samples were preserved in liquid nitrogen for shore-based studies.

The combined observations along this transect of sites show that gas hydrate occurs within coarser-grained turbidite sands and silts. The occurrence of gas hydrate appears to be controlled by several factors, including (1) local methane solubility linked with pore-water salinity, (2) fluid and gas advection rates, and (3) the availability of suitable host material such as coarse-grained sediments. The concentration of gas hydrate in the sediment changes significantly as these factors vary along the margin. 
In previously published models of gas hydrate formation in an accretionary margin, the highest concentrations of gas hydrate were expected to occur near the base of the gashydrate stability zone above the BSR, with concentrations gradually decreasing upward as a result of pervasive fluid advection from overall tectonically driven fluid expulsion. The results of Expedition 311, however, show that this model is too simple and that there are additional controlling factors. Although the data should provide evidence for widespread gas-hydrate-related BSRs, by far the largest concentrations of gas hydrate are observed well above the base of the gashydrate stability zone, at a point where the amount of methane in the pore fluid exceeded the local methane solubility threshold. This condition was most evident at Sites U1326 and U1327, where gas hydrate was observed in sections several tens of meters thick at shallow depths of $\sim 100 \mathrm{~m}$ and at concentrations exceeding $80 \%$ of the pore volume. Another site of very high gas-hydrate concentrations was the cold vent Site U1328, where beds containing massive forms of gas hydrate occurred within the top $\sim 40 \mathrm{~m}$ at concentrations exceeding $80 \%$ of the pore space, as a result of fluid and gas migrating upward along the underlying fault systems.

\section{Acknowledgements}

The authors wish to thank the Geological Survey of Canada and the University of Victoria for twenty years of site-survey research. Without those efforts, this expedition would not have been possible. This research used samples and data provided by the Integrated Ocean Drilling Program (IODP).

\section{IODP Expedition 311 Scientists}

M. Riedel (Co-chief Scientist), T.S. Collett (Co-chief Scientist), M. Malone (Expedition Project Manager/Staff Scientist), G. Guèrin, F. Akiba, M.-M. Blanc-Valleron, M. Ellis, Y. Hashimoto, V. Heuer, Y. Higashi, M. Holland, P.D. Jackson, M. Kaneko, M. Kastner, J.-H. Kim, H. Kitajima, P.E. Long, A. Malinverno, G. Myers, L.D. Palekar, J. Pohlman, P. Schultheiss, B. Teichert, M.E. Torres, A.M. Tréhu, J. Wang, U.G. Wortmann, and H. Yoshioka.

\section{References}

Hyndman, R.D., Spence, G.D., Chapman, N.R., Riedel, M., and Edwards, R.N., 2001. Geophysical studies of marine gas hydrate in northern Cascadia. In Paull, C.K., and Dillon, W.P. (Eds.), Natural Gas Hydrates, Occurrence, Distribution and Detection. Geophys. Monogr., 124:273-295.

Hyndman, R.D., and Davis, E.E., 1992. A mechanism for the formation of methane hydrate and seafloor bottom-simulating reflectors by vertical fluid expulsion. J. Geophys. Res., 97:7025-7041.

MacKay, M.E., Jarrard, R.D., Westbrook, G.K., and Hyndman, R.D., 1994. Origin of bottom-simulating reflectors: geophysical evidence from the Cascadia accretionary prism. Geology, 22(5):459-462. doi:10.1130/0091-7613(1994)022<0459: OOBSRG $>2.3 . \mathrm{CO} ; 2$
Paull, C.K., and Ussler, W., III, 1997. Are low salinity anomalies below BSRs a consequence of interstitial gas bubble barriers? Eos, Trans. Am. Geophys. Union, 78:F339.

Riddihough, R.P., 1984. Recent movements of the Juan de Fuca plate system. J. Geophys. Res., 89:6980-6994.

Riedel, M., Spence, G.D., Chapman, N.R., and Hyndman, R.D., 2002. Seismic investigations of a vent field associated with gas hydrates, offshore Vancouver Island. J. Geophys. Res., 107(B9):2200. doi:10.1029/2001JB000269

Riedel, M., Novosel, I., Spence, G.D., Hyndman, R.D., Chapman, R.N., Solem, R.C., and Lewis, T., 2006. Geophysical and geochemical signatures associated with gas hydrate related venting at the North Cascadia Margin. GSA Bulletin, Geol. Soc. Amer. Bull., 118 (no. 1-2): 23-38; doi: 10.1130/B25720.1.

von Huene, R., and Pecher, I.A., 1998. Vertical tectonics and the origins of BSRs along the Peru margin. Earth Planet Sci. Lett., 166(1-2):47-55. doi:10.1016/S0012-821X(98)00274-X

Westbrook, G.K., Carson, B., Musgrave, R.J., et al., 1994. Proc. ODP, Init. Repts., 146 (Pt. 1): College Station, TX (Ocean Drilling Program).

Wood, W.T., Gettrust, J.F., Chapman, N.R., Spence, G.D., and Hyndman, R.D., 2002. Decreased stability of methane hydrates in marine sediments owing to phase-boundary roughness. Nature (London, $U . \quad$ K.), 420:656-660. doi:10.1038/nature01263

Xu, W., and Ruppel, C., 1999. Predicting the occurrence, distribution, and evolution of methane gas hydrate in porous marine sediments. J. Geophys. Res., 104(B3):5081-5096. doi:10.1029/ 1998JB900092

Zuehlsdorff, L., and Spiess, V., 2004. Three-dimensional seismic characterization of a venting site reveals compelling indications of natural hydraulic fracturing. Geology, 32(2):101-104. doi:10.1130/G19993.1

\section{Authors}

Michael Riedel, Department of Earth and Planetary Sciences (EPS), Room 238, Adams Building, 3450 University Street, McGill Unviersity, Montreal, Quebec, H3A 2A7, Canada, e-mail: mriedel@eps.mcgill.ca

Timothy S. Collett, U.S. Geological Survey, Denver Federal Center, Box 25046, MS-939 Denver, Colo. 80225, U.S.A.

Mitchell J. Malone, Integrated Ocean Drilling Program, Texas A\&M University, 1000 Discovery Drive, College Station, Texas 77845-9547, U.S.A.

and the IODP Expedition 311 Scientists.

\section{Related Web Links}

http://iodp.tamu.edu/publications/PR/311PR/311PR.html http://gsc.nrcan.gc.ca/gashydrates/index_e.php http://ess.nrcan.gc.ca/2002_2006/ghff/iodp_e.php http://geophys.seos.uvic.ca/hydrates.html http://web.uvic.ca/acoustic/gashyd.html http://web.uvic.ca/ceor/iodp/

\section{Figure Credits}

Fig. 1: map from D. Kelly and J. Delaney, University of Washington and C. Barnes, C. Katnick, NEPTUNE Canada, University of Victoria 